\title{
Nagssugtoqidian granulite facies metamorphism in the Holsteinsborg region, West Greenland
}

\author{
Lindsay M. Davidson
}

\begin{abstract}
The rocks of the Holsteinsborg district were subjected to conditions of granulite facies metamorphism throughout and for some time after the period of ductile Nagssugtoqidian deformation. Within this span of time the pressure and temperature conditions did not remain stable and may be shown to have varied considerably. Zoning of $\mathrm{Al}$ in orthopyroxene coexisting with garnet, and of $\mathrm{Mg}$ and $\mathrm{Fe}$ in coexisting orthopyroxene and garnet, and clinopyroxene and garnet are interpreted as evidence of gradual cooling following the peak of metamorphism. Zoning of $\mathrm{Ca}$ and $\mathrm{Al}$ in coexisting clinopyroxene and plagioclase is interpreted as an indication of decreasing pressure. The assemblage orthopyroxene, sillimanite and quartz was stable during the peak of Nagssugtoqidian metamorphism and is considered to indicate extreme conditions, approaching $900^{\circ} \mathrm{C}, 9.5$ kbar. Pyroxene thermometry suggests that peak temperatures exceeded $800^{\circ} \mathrm{C}$.
\end{abstract}

\section{Introduction}

The principal aim of this paper is to demonstrate the sense of variation of pressure and temperature $(P T)$ conditions during the period of Nagssugtoqidian granulite facies metamorphism. An estimate is also made of the absolute values of $P T$ which affected the rocks of the Holsteinsborg area during this period. It is not intended either to formally discuss the methods of geothermometry and geobarometry employed in this study or to consider in detail the sources of error in these methods. Both points will however be treated briefly.

\section{Geological setting}

The rock samples discussed in this paper were taken from the area north of Holsteinsborg, West Greenland (fig. 1), the geology of which has been described by Davidson (1978). The sample numbers referred to in the text and fig. 1 are those of the Greenland project, University of Liverpool. Lithologies in the Holsteinsborg region show wide variation and include metasediments of quartzitic and pelitic compositions in addition to meta-igneous rocks of a range of compositions and also a suite of mixed tonalitic to granodioritic gneisses of indeterminate origin.

The structural history of the area is long and complex, and it seems likely that many of the earlier structures were formed during Archaean times. The last phase of regional deformation is considered to be of Nagssugtoqidian age. Folds formed during this phase are generally 


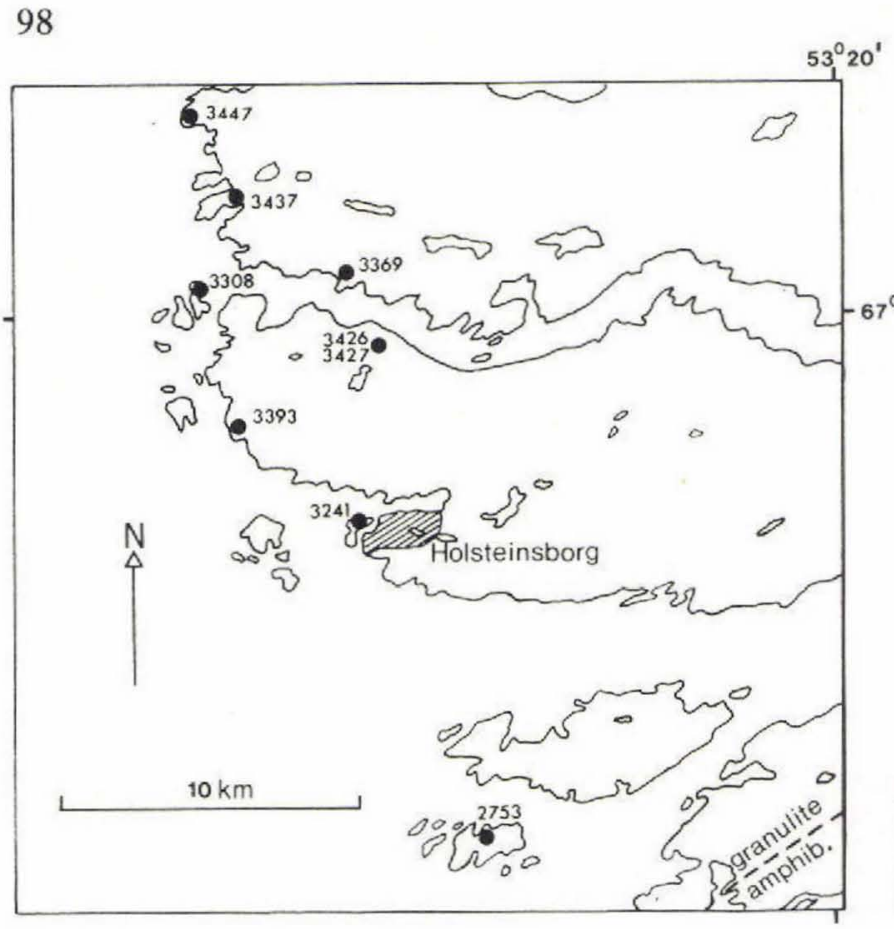

Fig. 1. Sample location map. The boundary between amphibolite facies and granulite facies is shown.

of large wavelength and amplitude, are of ENE-WSW trend and are overturned towards the SSE. Granulite facies conditions of metamorphism affected the area prior to, during and for some time after the duration of this deformation.

\section{Mineral chemistry}

The mineral analyses used in this study were performed at the University of Manchester on a Cambridge Geoscan electron microprobe with an energy dispersive system. $\mathrm{Fe}^{3+}$ was calculated on the basis of stoichiometry. The analyses are available from the author on request.

Analyses were made of grain centre and grain edge compositions of four or more grains of each major phase in each of the samples. In many cases averages were made of the centre or of the edge analyses of any one phase in a sample in order to improve the accuracy of site occupation calculations for $\mathrm{Al}$, and of $\mathrm{Fe}^{3+}$ determination. Due to the cut effect and the averaging of analyses it is very unlikely that the maximum extent of chemical zoning in any phase will be reyealed by this procedure, but the correct sense of zoning may be determined and a minimum value put on the amount. 
Fig. 2. $P T$ conditions calculated from equation 12 of Wood (1974) for the proportion of alumina in orthopyroxene coexisting with garnet. $\mathrm{c}$ - grain centre analysis, $\mathrm{e}-$ grain edge analysis, av.e. - average of grain edge analyses, ex.e. grain edge analysis showing maximum zoning.

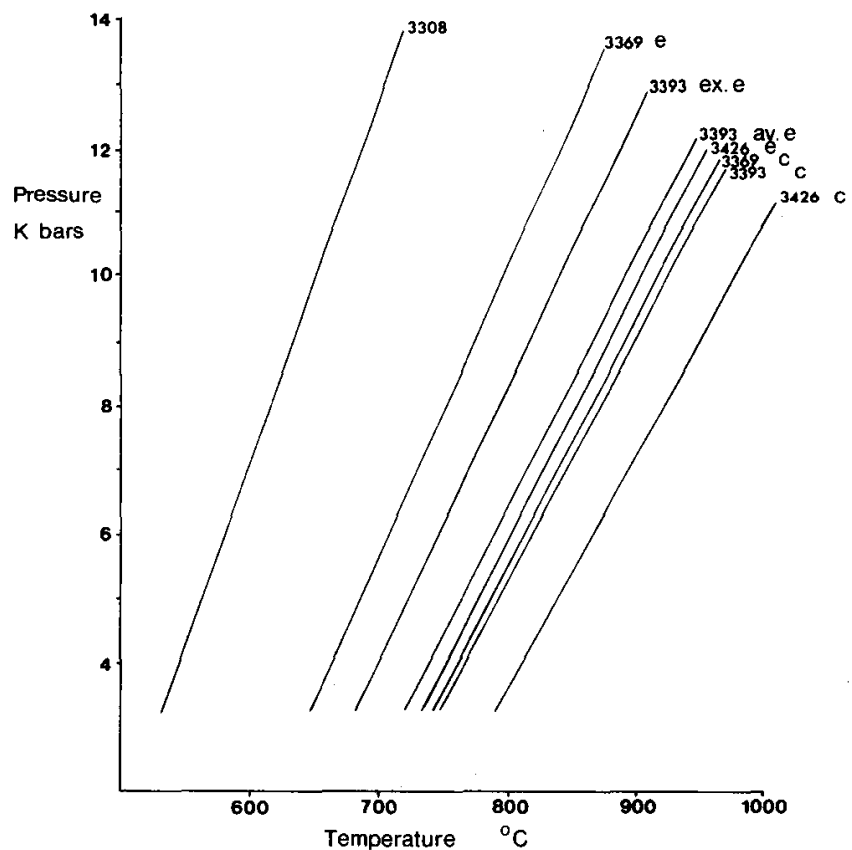

\section{Zoning of $\mathrm{Al}$ in pyroxenes}

In the samples studied both orthopyroxene and clinopyroxene were consistently found to be zoned with respect to $\mathrm{Al}$. In every case $\mathrm{Al}$ decreased in concentration from grain centre to grain edge, with approximately equal variation in the proportions in octahedral and tetrahedral coordination. For example in the orthopyroxene of sample 3426 the proportion in tetrahedral coordination, i.e. substituting for $\mathrm{Si}$, falls from 0.185 to 0.127 , while that in octahedral coordination, i.e. the M1 cation site, falls from 0.183 to 0.129 . It is clear from the analyses that the absolute proportion of $\mathrm{Al}$ in either pyroxene is strongly dependent on bulk chemical composition of the rock. However the same sense of zoning was found in pyroxenes of both very high and very low $\mathrm{Al}$ content and this feature is considered to be independent of bulk composition.

\section{Al in orthopyroxene coexisting with garnet}

A calibration in terms of $P$ and $T$ of the Al content of orthopyroxene in coexistence with garnet has been made by Wood \& Banno (1973) and revised by Wood (1974). The calibration indicates that the $\mathrm{Al}$ content of orthopyroxene in this association increases with rising temperature or with falling pressure.

The $P T$ determinations made by application of equation 12 of Wood (1974) to centre and edge analyses of orthopyroxenes in garnet bearing Nagssugtoqidian rocks are shown in fig. 2. The effect of zoning in samples 3369,3426 and 3393 is to move the calculated equili- 
brium curves to higher pressures/lower temperatures for analyses of grain edges relative to those of grain centres. The changes in $P$ or $T$ required are as follows:

$$
\begin{array}{rrr} 
& \triangle T, P \text { const. } & \triangle P, T \text { const. } \\
3426 & -75^{\circ} \mathrm{C} & +2900 \text { bar } \\
3369 & -120^{\circ} \mathrm{C} & +5100 \mathrm{bar} \\
3393 & -80^{\circ} \mathrm{C} & +3150 \mathrm{bar}
\end{array}
$$

Therefore the minimum estimates of the changes in physical conditions necessary to produce the observed zoning are an increase in pressure of 3 to $5 \mathrm{kbar}$ or a decrease in temperature of the order of $100^{\circ} \mathrm{C}$. It is believed that the explanation of decreasing temperature is more reasonable from a geological point of view and this conclusion is supported by other lines of evidence as discussed below.

Possible errors in the determination of $P$ and $T$ by this method may arise from two sources. O'Hara (1977) has suggested that the experimental procedures followed by Wood (1974) may have led to overestimation of $\mathrm{Al}$ in orthopyroxene coexisting with garnet. This would imply that the calibration used here overestimates pressures and underestimates temperatures. Another problem lies in the requirement of this method that the Al content of orthopyroxene be accurately divided into that of octahedral and of tetrahedral coordination. This division is highly sensitive to minor analytical errors, especially in the amount of Si, and therefore may be a source of major errors in $P T$ determination. Nevertheless it is unlikely that the slope of the equilibrium curves would change with correction of errors and hence the relative changes in $P T$ indicated in fig. 2 are likely to be correct.

\section{Ca Tschermak's component in clinopyroxene coexisting with plagioclase}

Wells (1976) produced a calibration of the partition of Ca Tschermak's component (CaTs) between clinopyroxene and plagioclase as a function of $P$ and $T$. The procedure of Wells (1976) has been adopted here with the exceptions that the proportion of CaTs in clinopyroxene has been calculated in a slightly different manner, as discussed in the appendix to this paper, and that the values of $\Delta H^{\circ}=5734 \mathrm{cal}$ and $\Delta S^{\circ}=-2.79 \mathrm{cal} \mathrm{deg}^{-1}$ (Wood, 1976, pers. comm.) have been used for the reaction

$$
\underset{\mathrm{An}}{\mathrm{CaAl}_{2} \mathrm{Si}_{2} \mathrm{O}_{8}}=\underset{\mathrm{CaAl}}{\mathrm{CaA}} \mathrm{SiO}_{6}+\underset{\mathrm{Ctz}}{\mathrm{SiO}_{2}}
$$

in preference to the values given by Wells. The thermodynamic data indicate that with increasing temperature or pressure the. CaTs component will become increasingly concentrated in clinopyroxene relative to plagioclase.

The results of application of this method to Nagssugtoqidian samples are given in fig. 3 . The variation between the curves derived from grain centre and grain edge analyses is the result of consistent zoning of $\mathrm{Al}$ in clinopyroxene, decreasing towards the edges, and consistent reverse zoning of plagioclase, i.e. $\mathrm{Ca}$ and $\mathrm{Al}$ increasing towards grain edges. Zoning of $\mathrm{Ca}$ in clinopyroxene is of inconsistent sense, but this may be due to the involvement of $\mathrm{Ca}$ in several different cation exchange reactions, e.g. with hornblende, not discussed in this paper. 
Fig. 3. $P T$ conditions calculated for the proportion of Ca Tschermak's component in clinopyroxene coexisting with plagioclase. The ticked points on the curves are the temperatures calculated by the pyroxene thermometer of Wells (1977) for the relevant samples.

$c$ - grain centre analysis, $e$ - grain edge analysis.

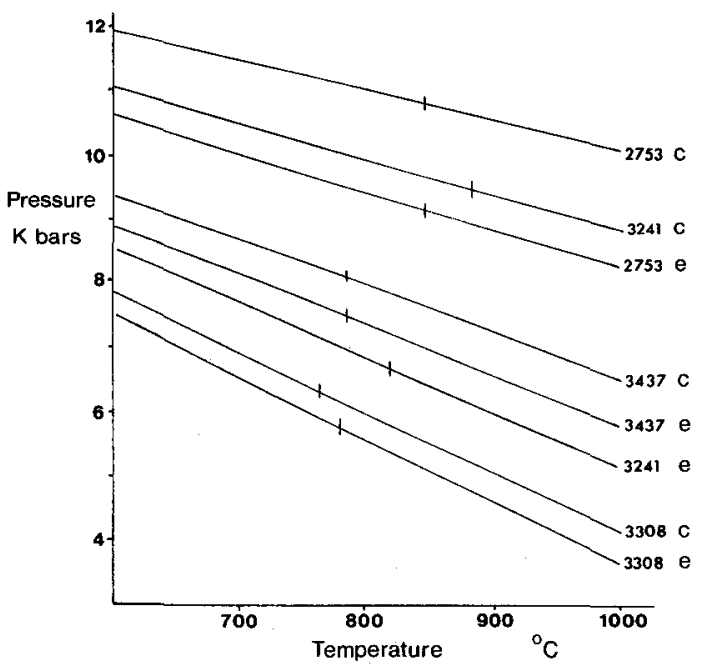

It is clear from fig. 3 that the observed zoning could have been brought about by a decrease either in temperature or pressure. However a temperature decrease alone could not completely account for the change calculated for sample 3241 since the required decrease at constant pressure would be in excess of $400^{\circ} \mathrm{C}$ and would encompass temperatures well outside the generally accepted range for granulite facies metamorphism. Hence it is likely that a decrease in pressure, probably accompanied by a decrease in temperature, acted to produce the observed zoning patterns.

\section{$\mathrm{Mg}$, Fe exchange reactions}

\section{$\mathrm{Mg}, \mathrm{Fe}$ distribution between coexisting clinopyroxene and garnet}

Råheim \& Green (1974) produced a calibration in terms of $P$ and $T$ of the distribution of $\mathrm{Mg}$ and $\mathrm{Fe}$ between coexisting clinopyroxene and garnet. This study shows the distribution coefficient

$$
K_{\mathrm{D}}=\frac{(\mathrm{FeO} / \mathrm{MgO})^{\mathrm{Gar}}}{(\mathrm{FeO} / \mathrm{MgO})^{\mathrm{Cpx}}}
$$

to be largely dependent on temperature and to be relatively insensitive to pressure changes. This is illustrated in fig. 4.

Garnet and clinopyroxene coexist in two of the analysed samples, 3308 and 2753, of the Nagssugtoqidian gneisses. In both samples clinopyroxene and garnet are zoned in $\mathbf{M g}$ and $\mathrm{Fe}$, with clinopyroxene becoming $\mathrm{Mg}$ rich towards grain margins and garnet becoming $\mathrm{Fe}$ rich. This is illustrated for sample 2753 in fig. 5 . The effect of the zoning is to raise the value of $K_{\mathrm{D}}$ from centre to edge determination, which with reference to fig. 4 is taken to imply partial re-equilibration of the phases under conditions of gradually decreasing temperature. 


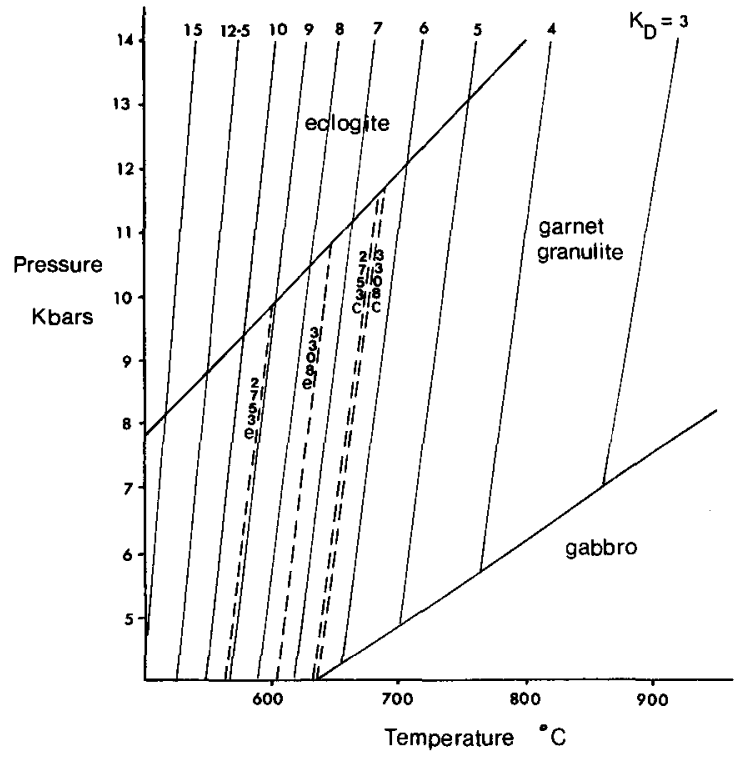

Fig. 4. The distribution coefficient $K_{\mathrm{D}}=$ $(\mathrm{FeO} / \mathrm{MgO})^{\mathrm{Gar}} /(\mathrm{FeO} / \mathrm{MgO})^{\mathrm{Cpx}}$ as a function of $P T$ (after Råheim \& Green 1974), with the calculated curves for samples 3308 and 2753. $\mathrm{c}$ - grain centre analysis, $\mathrm{e}$ - grain edge analyses.

In assessing the reliability of the Råheim \& Green (1974) calibration as used here it must be pointed out that the experimental work was carried out under eclogite facies $P T$ conditions on material of basaltic composition and the extrapolation of the results to granulite facies conditions and to rock compositions other than basaltic may introduce significant errors. However the relative change in temperature implied in fig. 4 is considered to be of the correct sense. The relatively low temperatures of equilibration, around $600^{\circ} \mathrm{C}$, calculated for these samples are thought to be underestimates but may also be influenced by the fact that garnet in these rocks is of late, post-tectonic growth (Davidson, 1978) and the temperatures may refer to the waning stages of granulite facies metamorphism.

\section{$\mathrm{Mg}, \mathrm{Fe}$ distribution between coexisting orthopyroxene and garnet}

Partial thermodynamic data were derived by Davidson (1978) for the reaction:

$$
\begin{array}{ccc}
3 \mathrm{Mg}_{2} \mathrm{Si}_{2} \mathrm{O}_{6} & +2 \mathrm{Fe}_{3} \mathrm{Al}_{2} \mathrm{Si}_{3} \mathrm{O}_{12}= \\
\mathrm{Mg} \mathrm{Opx} & \mathrm{Fe} \mathrm{Gar} & \mathrm{Fe} \mathrm{Fi}_{2} \mathrm{Si}_{2} \mathrm{O}_{6}
\end{array}
$$

These data are:

$$
\begin{aligned}
& \Delta V^{\circ}=0.1326 \mathrm{cal} \mathrm{bar}^{-1} \\
& \triangle S^{\circ}=39.05 \mathrm{cal} \mathrm{deg}^{-1}
\end{aligned}
$$

The slope of the reaction boundary for the pure phases is given by the Clausius - Clapeyron equation (Wood \& Fraser, 1976):

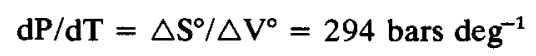




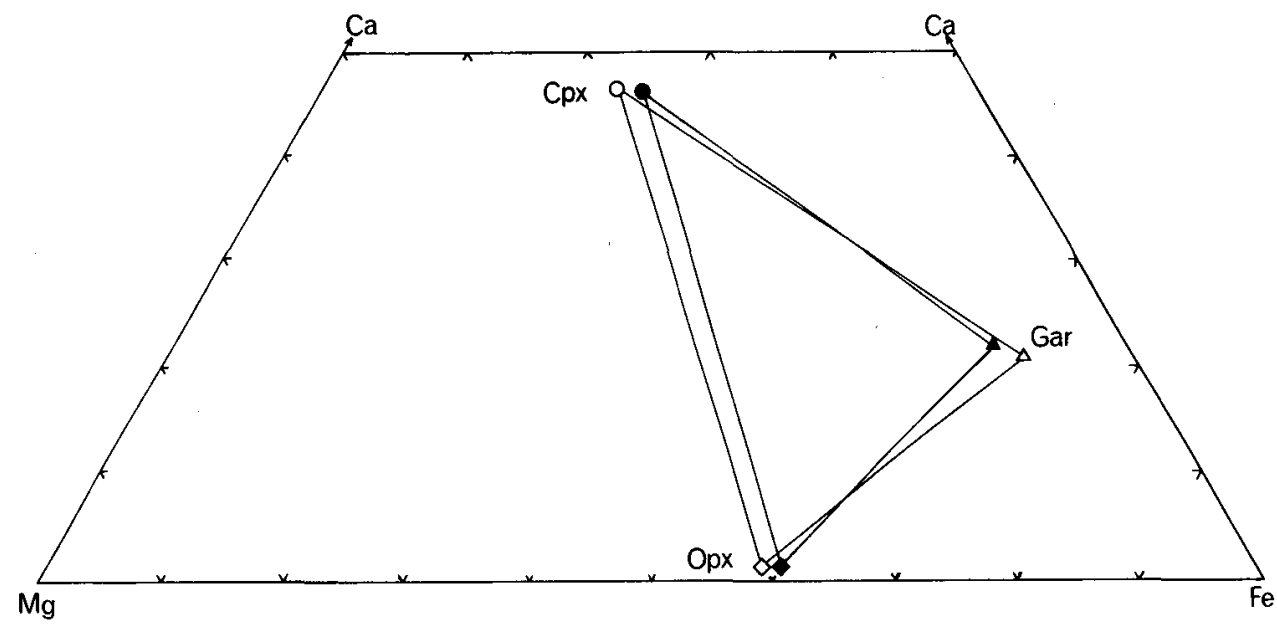

Fig. 5. Mg and Fe zoning in the phases clinopyroxene, Cpx, orthopyroxene, Opx, and garnet, Gar, in sample 2753. Filled symbols - grain centre analyses, open symbols - grain edge analyses.

which implies that the reaction is dependent mainly on temperature and is relatively insensitive to changes in pressure. With rising temperature the reaction would be expected to proceed from left to right, producing Fe rich orthopyroxene and $\mathrm{Mg}$ rich garnet. Conversely decreasing temperature would produce progressively more $\mathrm{Fe}$ rich garnet and $\mathrm{Mg}$ rich orthopyroxene. Since a value of $\Delta \mathrm{H}^{\circ}$ is presently unavailable for this reaction it is not possible to calculate absolute temperatures of equilibrium, but details of zoning in orthopyroxene and garnet may be used to derive relative changes in temperature with time.

Three of the analysed Nagssugtoqidian samples, 2753, 3393 and 3426, contain coexisting orthopyroxene and garnet. In each example the garnet is zoned with Fe increasing towards margins and the orthopyroxene with $\mathbf{M g}$ increasing towards margins. This is shown for sample 2753 in fig. 5 . The implication therefore is that partial re-equilibration of these phases took place under conditions of falling temperature.

As noted above the garnet in sample 2753 is of late growth and some doubt may exist as to whether or not it ever equilibrated with the cores of the pyroxenes which are of earlier growth. However this is not the case for samples 3369 and 3426 in which both pyroxene and garnet were of early pre-tectonic growth. The consistency of sense and magnitude of the zoning observed in all three rocks suggests that this feature reflects the same general trend of change in physical conditions during the relatively late stages of metamorphism.

\section{The absolute $P T$ conditions of Nagssugtoqidian granulite facies metamorphism}

A number of difficulties are encountered in the attempt to establish the absolute $P T$ conditions of the rocks under consideration. The difficulties fall into three main categories.

Firstly it is clear from the preceeding sections of this paper that considerable variation of temperature and probably also of pressure occurred during the period of granulite facies metamorphism of the Nagssugtoqidian rocks. Consequently the study must be directed 


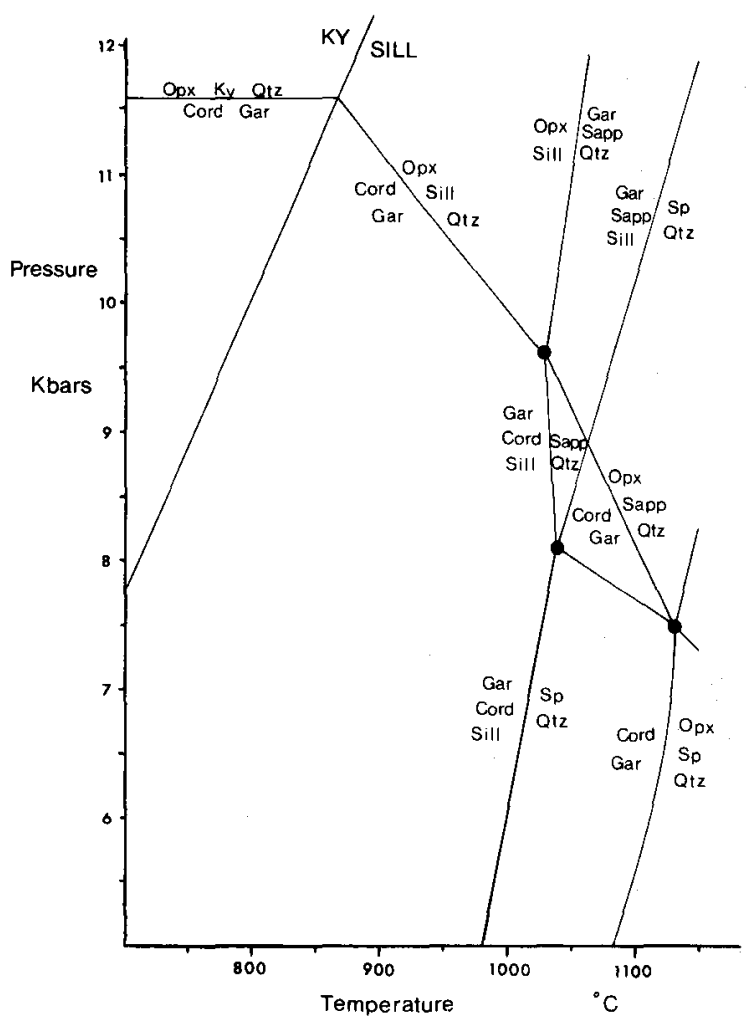

Fig. 6. Phase relations in pelitic compositions at high temperatures and pressures, after Hensen \& Green (1973). The univariant reaction boundaries and three invariant points are shown.

towards establishing a range of temperature and a range of pressure rather than a unique value for either.

Secondly since few methods of geothermometry/barometry may evaluate temperature or pressure independently of each other it is generally necessary to combine two or more methods in order to extract absolute $P$ and $T$ values. However since it is known that both $P$ and $T$ varied with time it must be established that the different reaction equilibria used for the combined methods took place at approximately the same time during metamorphism. O'Hara (1977) has shown the significance of this problem when dealing with high grade metamorphic rocks.

Thirdly the values of $P$ and $T$ derived from any method of geothermometry/barometry are only as valid and accurate as the theory and experiments used in their calibration. The errors derived from these sources would require detailed study outside the scope of this paper before they could be properly evaluated.

\section{The orthopyroxene, sillimanite, quartz assemblage}

Experimental work in pelitic systems by Hensen \& Green $(1971,1972,1973)$ has shown that the assemblage orthopyroxene, sillimanite, quartz should be stable only under conditions of extreme metamorphism, above $900^{\circ} \mathrm{C}, 9.5 \mathrm{kbar}$ (fig. 6). At lower temperatures and pressures the assemblage breaks down by the reaction: 
Fig. 7. Photomicrograph of the assemblage orthopyroxene (dark grey), sillimanite (pale grey), and quartz (low relief matrix). Minor biotite is also present. Note the idioblastic form of sillimanite which occurs both as large laths and as minute needles. The scale bar represents $0.5 \mathrm{~mm}$. Sample 3427.

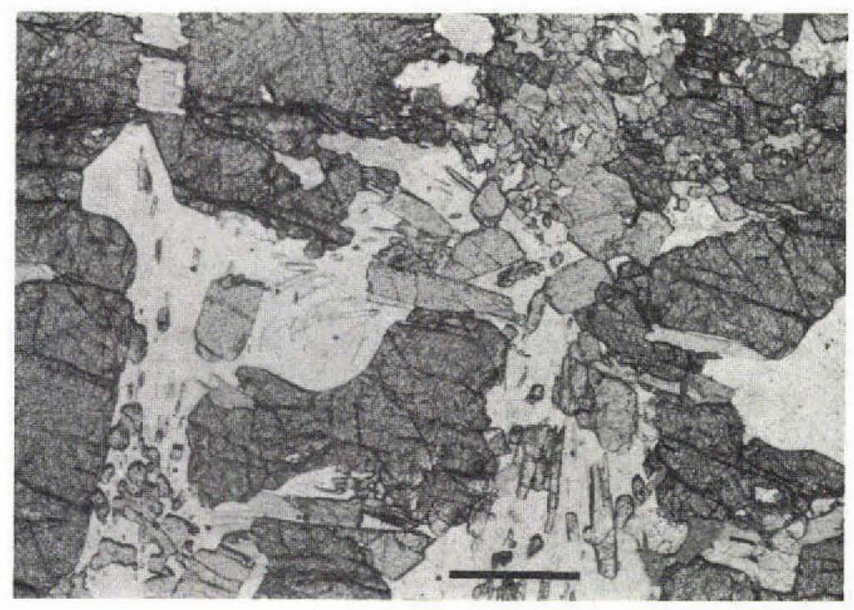

$$
\mathrm{Opx}+\mathrm{Sill}+\mathrm{Qtz}=\mathrm{Cord}+\mathrm{Gar}
$$

which Hensen \& Green regard to be univariant in most natural pelitic compositions. In support of the experimental evidence is the extreme rarity of the assemblage Opx, Sill, Qtz in natural rocks, the only reported occurrences being in the Aldan shield (Khlestov, 1964; Marakushev \& Kudryavtsev, 1965), the Anabar Massif (Lutts \& Kopaneva, 1968) and Finland (Eskola, 1952), while the assemblage Cord, Gar is of widespread occurrence (Hensen, 1977).

The assemblage Opx, Sill, Qtz is found in two samples, 3426 and 3427, of Nagssugtoqidian metapelitic rocks. Photomicrographs of this association are shown in figs. 7 and 8 . The assemblage of 3426 also includes cordierite and garnet, and shows mosaic intergrowths of idioblastic sillimanite and orthopyroxene surrounded by later cordierite. This sample leaves little doubt that conditions very close to those of the reaction boundary for Opx + Sill $+\mathrm{Qtz}=$ Cord + Gar were attained.

The experimental results of Hensen \& Green (1973) cannot, however, be directly related to the natural occurrence without some reservations. The most serious problem lies in the values of $\mathrm{Mg} / \mathrm{Mg}+\mathrm{Fe}$ measured for the ferromagnesian phases in 3426 (Cord $=0.88, \mathrm{Opx}$ $=0.73, \mathrm{Gar}=0.53$ ) which are very similar to the values quoted by Lutts \& Kopaneva (1968) for the Anabar Massif example, but are considerably less magnesian than predicted by Hensen \& Green (1973) for compositions close to the univariant boundary. Another problem concerns the fact that the reaction Opx + Sill + Qtz $=$ Cord + Gar cannot be strictly univariant in natural pelitic compositions, and although the effects of minor components, e.g. $\mathrm{Mn}, \mathrm{Ca}, \mathrm{Fe}^{3+}, \mathrm{H}_{2} \mathrm{O}$, may be individually small, certain combinations may seriously affect the conditions of equilibrium.

Despite the problems involved in relating the experimental results to the natural assemblages it is believed that sufficient evidence exists to suggest that extreme conditions, perhaps approaching $900^{\circ} \mathrm{C}, 9.5 \mathrm{kbar}$, may have been reached at the peak of Nagssugtoqidian metamorphism. 


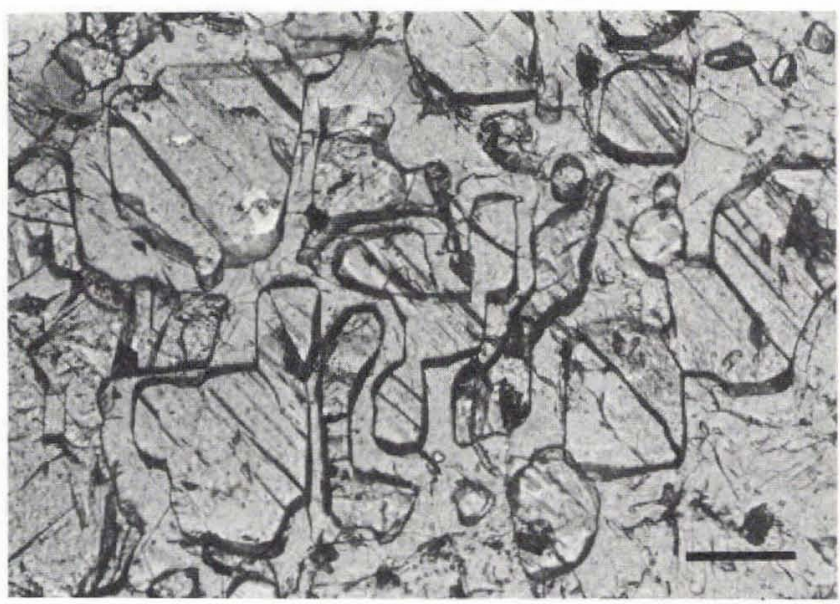

Fig. 8. Photomicrograph showing the mosaic intergrowth of orthopyroxene (medium grey), sillimanite (pale grey with conspicuous diagonal cleavage) and cordierite (low relief matrix). Minor biotite is also present and quartz occurs as blebs within the cordierite. Note the strong idioblastic form of sillimanite. The scale bar represents $0.1 \mathrm{~mm}$. Sample 3426.

\section{Pyroxene thermometry}

Wood \& Banno (1973) formulated a method of geothermometry based on the mutual solid solution of coexisting orthopyroxene and clinopyroxene. The calibration was updated by Wells (1977) to be consistent with all the experimental data available at that time.

Application of the Wells (1977) calibration to the Nagssugtoqidian samples yields the following results:

$\begin{array}{cc}\text { Sample } & \text { Temp. }{ }^{\circ} \mathrm{C} \\ 2753 & 820 \\ 3308 & 780 \\ 3447 & 864 \\ 3437 & 783 \\ 3241 & 815\end{array}$

The analyses used were taken from grain edges. Grain centre analyses give slightly different results for some samples but do not give consistently higher or lower values.

Two main sources of uncertainty must be considered in the assessment of these results. O'Hara (1977) is critical of the experimental results used in the Wood \& Banno (1973) calibration, and suggests that temperatures calculated by this method are overestimated by $100-200^{\circ} \mathrm{C}$. However the Wells (1977) calibration which incorporates more recent experimental data gives slightly higher temperatures for the Nagssugtoqidian rocks than does the Wood \& Banno (1973) calibration. A second point is that either method may only give an estimate of the temperature at which exsolution processes ceased to operate within the pyroxenes. The granulite facies pyroxenes examined in this study frequently contain exsolution lamellae and hence the temperatures recorded, even if no errors are assumed, must be regarded as lower than those of peak metamorphism.

The pyroxene temperatures derived from the Wells (1977) calibration are indicated on the relevant curves in fig. 3 in order that some pressure estimates may be made. This shows that the rocks may have been subjected to pressures of $8 \pm 2 \mathrm{kbar}$ during granulite facies 
metamorphism. This procedure combines the errors of the two independent calibrations and also presupposes that the redistribution of $\mathrm{Ca}$ and $\mathrm{Al}$ between clinopyroxene and plagioclase ceased to operate at approximately the same lower limits of $P T$ as the process of exsolution in pyroxenes. Clearly there is scope for large errors in this pressure estimate.

\section{Conclusions}

It has been shown that the mineral zoning detected by microprobe analysis in samples of Nagssugtoqidian granulite facies rocks is consistent with a history of gradual cooling and uplift following the peak of metamorphism. No mineral chemistry data or petrographic detail is believed to relate to the time and conditions prior to peak metamorphism and hence the early metamorphic history remains unknown.

Peak conditions are believed to have been very high, perhaps reaching $900^{\circ} \mathrm{C}, 9.5 \mathrm{kbar}$. This is indicated by the experimental work of Hensen \& Green (1973) on the stability field of the assemblage Opx, Sill, Qtz which is found in samples of Nagssugtoqidian metapelites. Subsequent cooling is suggested by the zoning of $\mathrm{Al}$ in orthopyroxene coexisting with garnet, and by the zoning of $\mathrm{Fe}$ and $\mathrm{Mg}$ in garnet and orthopyroxene, and garnet and clinopyroxene. A gradual decrease in pressure is suggested by the zoning of $\mathrm{Ca}$ and $\mathrm{Al}$ in coexisting clinopyroxene and plagioclase. Petrographic evidence such as the rimming of clinopyroxene by garnet, replacement of pyroxenes by hornblende and the late growth of cordierite in pelitic samples (Davidson, 1978) supports the conclusion that retrogressive conditions dominated the later period of Nagssugtoqidian metamorphism. Pyroxene thermometry indicates that temperatures of around $800^{\circ} \mathrm{C}$ were surpassed during peak metamorphism.

The retrogressive reactions observed all took place among mineral assemblages indicative of the granulite facies, and the $P T$ changes inferred are therefore entirely intra-granulite facies. It is considered that complete retrogression at a late stage in the metamorphic history to amphibolite facies assemblages was inhibited by the low values of $\boldsymbol{P}_{\mathrm{H}_{2}} \mathrm{O}$ in the rocks and also by the absence of strong penetrative deformation at this time.

\section{Appendix}

The proportion of $\mathrm{Ca}$ Tschermak's component, $X \mathrm{CaTs}$, where $\mathrm{CaTs}=\mathrm{CaAl}_{2} \mathrm{SiO}_{6}$, has been calculated in this study in the following manner. It is assumed that $\mathrm{Al}$ in octahedral coordination, $\mathrm{Al}^{\mathrm{vi}}$, occupies the M1 structural site (Wood \& Banno, 1973), and that each $\mathrm{Al}^{\text {vi }}$ is linked to an $\mathrm{Al}$ in tetrahedral coordination, $\mathrm{Al}^{\mathrm{iv}}$, in order to maintain local charge balance. $\mathrm{Ca}$ is assumed to occupy the M2 structural site in clinopyroxene (Wood \& Banno, 1973). Ideal mixing of CaTs in clinopyroxene is assumed (Wood, 1976). The activity of CaTs in clinopyroxene is therefore taken to be equal to $X$ CaTs which is given by:

$$
X \mathrm{CaTs}=\mathrm{Al}_{\mathrm{M} 1}{ }^{\mathrm{vi}} \cdot \mathrm{Ca}_{\mathrm{M} 2}
$$

An activity coefficient of 1.28 as determined by Orville (1972) has been used to relate the proportion of anorthite in plagioclase to its activity.

Acknowledgements. During the course of this work I have benefitted from discussion with a number of people, including M. P. Atherton, G. King, J. Watterson, P. R. A. Wells, and B. J. Wood. I gratefully acknowledge receipt of a N.E.R.C. research studentship. 


\section{References}

Davidson, L. M. 1978: Granulite facies rocks bordering the Ikertôq shear belt, central West Greenland. Unpub. Ph.D. thesis, University of Liverpool.

Eskola, P. 1952: On the granulites of Lapland. Am. J. Sci. Bowen Volume, 133-171.

Hensen, B. J. 1977: Cordierite - garnet bearing assemblages as geothermometers and barometers in granulite facies terrains. Tectonophysics 42, 73-89.

Hensen, B. J. \& Green, D. H. 1971: Experimental study of the stability of cordierite and garnet in pelitic compositions at high pressures and temperatures; 1 . Compositions with excess alumino-silicate. Contr. Mineral Petrol. 33, 309-330.

Hensen, B. J. \& Green, D. H. 1972: Experimental study of the stability of cordierite and garnet pelitic compositions at high pressures and temperatures; II. Compositions without excess alumino-silicate. Contr. Mineral. Petrol. 35, 331-354.

Hensen, B. J. \& Green, D. H. 1973: Experimental study of the stability of cordierite and garnet in pelitic compositions at high pressures and temperatures; III. Synthesis of experimental data and geological implications. Contr. Mineral. Petrol. 38, 151-166.

Khlestov, V. V. 1964: Garnets from cordierite bearing rocks of the Sharyzhalgay Complex (Southwestern Transbaikal). Dokl. Acad. Sci. USSR, Earth Sci. Sect. 154, 105-108.

Lutts, B. G. \& Kopaneva, L. N. 1968: A pyrope - sapphirine rock from the Anabar Massif and its conditions of metamorphism. Dokl. Acad. Sci. USSR, Earth Sci. Sect. 179, 161-163.

Marakushev, A. A. \& Kudryavtsev, V. A. 1965: Hypersthene - sillimanite paragenesis and its petrologic implication. Dokl. Acad. Sci. USSR, Earth Sci. Sect. 164, 145-148.

O'Hara, M. J. 1977: Thermometry and barometry of the Scourie gneisses. Unpublished preprint and personal communication.

Orville, P. M. 1972: Plagioclase cation equilibria with aqueous chloride solution: results at $700^{\circ} \mathrm{C}$ and 2000 bars in the presence of quartz. Am. J. Sci. 272, 234-272.

Råheim, A. \& Green, D. H. 1974: Experimental determination of the temperature and pressure dependence of the $\mathrm{Fe}-\mathrm{Mg}$ partition coefficient for coexisting garnet and clinopyroxene. Contr. Mineral. Petrol. 48, 179-203.

Wells, P. R. A. 1976: Late Archaean metamorphism in the Buksefjorden region, Southwest Greenland. Contr. Mineral. Petrol. 56, 229-242.

Wells, P. R. A. 1977: Pyroxene thermometry in simple and complex systems. Contr. Mineral. Petrol. 62, 129-139.

Wood, B. J. 1974: The solubility of alumina in orthopyroxene coexisting with garnet. Contr. Mineral. Petrol. 46, 1-15.

Wood, B. J. 1976: Mixing properties of tschermakitic clinopyroxenes. Amer. Mineral. 61, 626-637.

Wood, B. J. \& Banno, S. 1973: Garnet - orthopyroxene and orthopyroxene - clinopyroxene relationships in simple and complex systems. Contr. Mineral. Petrol. 42, 125-139.

Wood, B. J. \& Fraser, D. G. 1976: Elementary thermodynamics for geologists. Oxford University Press, Oxford. 303 pp.

The Jane Herdman Laboratories of Geology,

The University of Liverpool,

Brownlow Street,

Liverpool, L69 3BX,

U.K.
Present address: Esso Exploration and Production U.K., Block 5, The Centre, Walton-on-Thames, Surrey, U.K. 